
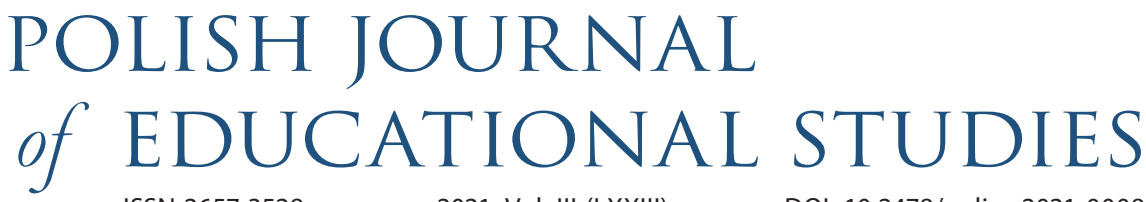

\title{
Inclusion of Doctoral Students with Disabilities within Higher Education
}

\author{
Tomasz Kasprzak
}

\begin{abstract}
The history of educating doctoral students with disabilities at Polish universities, at least in institutional terms, is not very long. From the very beginning, universities educated individuals with disabilities and it was possible as long as these people could cope on their own or with the help of their family and friendly academic staff. This study presents the situation of doctoral students with disabilities in the higher education system, indicates the results of research, as well as "good practices" and recommendations for the academic education system for the in-depth inclusion of people with disabilities in higher education.
\end{abstract}

KEY WORDS

disability, higher education, PhD student, inclusive education

\section{Introduction}

The model of doctoral education was subject to numerous transformations, and the position of doctoral students in the system of higher education and science varied (Kierznowski, 2018). The education of young researchers is at the center of many important topics in contemporary European and global debates. In Poland, a doctorate is treated only (or at least mainly) as an academic degree that opens an academic career, i.e. preparation for the work of an academic teacher. Therefore, there is still a belief that the best path of a scientific career is "apprenticeship" with a master and gaining experience in an environment in which you will stay "from the first paycheck to the golden watch" (Czerepaniak-Walczak, 2013, p. 69). Undoubtedly, obtaining an

1 Faculty of Education, University of Bialystok, Poland E-MAlL: t.kasprzak@uwb.edu.pl ORCID: 0000-0003-0955-3464 
academic degree is a turning point in the academic and socio-professional career of young people (Gromkowska-Melosik, 2020, p. 91). Obtaining a PhD is the culmination of academic achievement. It contains mastery of a certain problem field within the discipline, a sense of self-confidence and competence in building and disseminating new knowledge.

The last three decades have brought about wide changes in higher education. Numerous studies have confirmed the rapid increase in the demand for a university degree. This resulted in the massification of higher education. Stakeholders of universities (management, academic staff, doctoral students and students) had to face new challenges posed by "expansionism" (Powell \& Solga, 2011; Melosik, 2013; GromkowskaMelosik, 2020). The violent nature of this process made the democratization of access to higher education remain a politically controversial issue, arousing, above all, in periods of economic and social crises, many negative emotions among academic staff and students, the political class and journalists. Criticism of massification has encountered significant barriers in democratic countries. As higher education is not compulsory, and therefore the development of the institutions that offer it, and the negative consequences that result from it, such as the inflation of diplomas or a decline in the quality of teaching, the students themselves are responsible (Stankiewicz, 2015).

The article aims to present the history of higher education opening up to $\mathrm{PhD}$ students with disabilities in Poland and abroad. The study indicates how much - or perhaps - whether the approach to doctoral students with disabilities is changing at all in universities as educational institutions and in the academic environment. This study focuses on the problems and needs of PhD students with disabilities. The article presents the results of the research conducted so far on creating conditions for doctoral students with disabilities to fully participate in the education process, and also presents the activities undertaken so far in this respect in relation to doctoral students with disabilities. The present experience and challenges in the field of adapting academic education to the needs of people with various types of disabilities are outlined. The article is divided into two parts. The first presents the general situation of doctoral students with disabilities - the history of their education, as well as statistical data. The second part is devoted to the analysis of academic accessibility for people with disabilities in terms of the implementation of the principles of equal treatment and non-discrimination. When reading this article, it should be noted that the presented research results do not present a representative picture for the entire academic community in Poland and abroad. 


\section{Doctoral students with disabilities as a social category}

The history of access to higher education for people with disabilities is very short, as it is only a quarter of a century old. Of course, history provides us with examples of outstanding people who managed to obtain higher education despite their disability. Higher education does not function in isolation from the lower levels of education, and this is where young people come to universities. Hence, opening the university to people with disabilities is only one of the elements of thinking about the education of this social group. After World War II, the chances of people with disabilities to obtain education were limited to special schools, which were oriented at preparing the student for a relatively simple profession, most often based on manual work. The statistics clearly show it, as the percentage of people with disabilities who had primary education in 1988 was nearly 70\% (Śleboda, 2012, p. 117; Krzymowska, 2014). A person with a disability had to overcome two main obstacles on the way to higher education: 1) breaking the image of a person with a disability as a participant only in special education, and 2) gaining access to exclusive goods, such as higher education. The second of the above-mentioned obstacles concerns specific thinking about higher education (as a good which is generally available to very few) (Krzymowska, 2014). In the process of developing more effective internships for students and doctoral students with disabilities, universities today face the challenge of dealing with historical legacy. These challenges include the legacy of excluding people with disabilities from mainstream education, and the stereotypes and attitudes that continue to marginalize people with disabilities in society. Consequently, while legislation and policies can create a higher education environment that is sensitive to the needs of people with disabilities, this does not necessarily mean that public policies are transformed into effective social practices (Swart \& Greyling, 2011).

Higher education functioned as a form of elite education, accessible to the few, especially predisposed, and remained beyond the reach of many able-bodied citizens, especially those who experienced functional limitations. The political and economic changes that took place in Poland after 1989, the increase in educational aspirations in the society, the spread of the idea of inclusive education in theoretical and practical dimensions, combined with a decrease in the number of people entering adulthood due to the demographic low, contributed to an increase in the availability of higher education also for people with disabilities (Kilian, 2017). After 1989, Poland recorded a record increase in the number of students, to 1,953,832 people in the academic year 2005/2006, which meant a nearly five-fold increase. In the academic year 1990/1991, 403824 students studied in Poland. This phenomenon is known as the "educational boom". In the following years, the increase in higher education also included people with disabilities. In the academic year 1998/1999, 1,273,955 students studied in 
Poland, including 826 disabled students, who constituted $0.06 \%$ of the total number of students. In the academic year 2011/2012, 1,764,060 students were educated at 460 universities in Poland, including 30,249 students with disabilities. They constituted $1.7 \%$ of the total number of students. From the beginning of the $1990 \mathrm{~s}$, an extremely dynamic development of doctoral studies could be observed (Szulc, 2007; Brzezicki \& Pietrzak, 2018). In the academic year 1990/1991, 2,700 doctoral students attended these studies, while in $2016 / 2017$ nearly 40,700 people. It was a consequence of the greater availability of this form of extramural education, also at non-public universities. The observed increase in the number of doctoral students did not translate into the number of people holding a doctoral degree. In the 2016/2017 academic year, only 5,200 people opened the doctoral dissertation. In turn, the number of awarded doctoral degrees was nearly 6,000 . This may mean that many people undertook doctoral studies accidentally or have insufficient motivation to continue their studies. This may also result from the poor research competences of some doctoral students and the non-competitive nature of the selection of people for part-time studies (Całek et al., 2011; Brzezicki \& Pietrzak, 2018). Beata Mikołajczyk and Ryszard Naskręcki (2017) indicate that since 1990, over the next 25 years, the number of doctoral students in Poland has increased by about 15 times, from 2,695 to 40,600, respectively. A doctoral student has become a "mass product of Polish universities", and doctoral studies have ceased to be "a fully effective method of educating scientific staff". Relatively easy access to doctoral studies and relatively low criteria necessary to launch them resulted in a decrease in the level of candidates and, consequently, the quality of research and the quality of education.

Universities were slowly adapting their programs and infrastructure to the needs of people with disabilities. One of the first such universities was the University of Agriculture and Pedagogy in Siedlce (now the University of Natural Sciences and Humanities), where in 1994 an agreement was concluded between the Ministry of National Education and the Ministry of Labor and Social Policy on the establishment of the Center for Education and Rehabilitation of Disabled Persons (pl. Centrum Kształcenia i Rehabilitacji Osób Niepełnosprawnych). The initiator of the education and rehabilitation program was the then Rector - professor Lesław Szczerba. This program was aimed at enabling people with disabilities to function as students on equal rights - the possibility of full participation in didactic activities, as well as in scientific, social, cultural and sports life. Activities undertaken at the Center for Education and Rehabilitation of Disabled Persons include: patronage over the didactic process, coordination of the work of units supporting the education of people with disabilities (such as a speech therapy workshop, psychological clinic, typhloinformatics workshop), as well as stimulating the independence and effectiveness of studies of people with disabilities. The activity for disabled students of the University of Siedlce was the beginning of such solutions at all 
universities in Poland (Sztobryn-Giercuszkiewicz, 2016; Czerw, Karpuszenko, \& Kukla, 2019). The activity of the university in Siedlce became an inspiration for the next ones, which at the turn of the $20^{\text {th }}$ and $21^{\text {st }}$ centuries decided to launch special departments whose task was to take special care of students and doctoral students struggling with disabilities. In 2000, the University of Warsaw decided to do so, as the first one to create the Office for Persons with Disabilities (pl. Biuro ds. Osób Niepełnosprawnych), which resulted in an increase in the number of people with disabilities deciding to study higher education. One of the initiatives taken at that time was the "University for all" program, which focused not only on the ongoing support of people with disabilities, but also on the support of academic staff and systemic solutions related to, inter alia, with transport and university infrastructure. After five years, another Office for Persons with Disabilities was established at the Jagiellonian University, and at a similar time this direction of development was chosen by other Krakow universities (including the Krakow University of Technology, AGH University of Science and Technology, Pedagogical University) (Sztobryn-Giercuszkiewicz, 2016). Currently, universities, legally obliged to implement systemic solutions supporting students and doctoral students with disabilities in the teaching process and research, do so through the actions of the rector's representative for disabled people or the office for disabled people. Usually, these units are an advisory body to the university authorities. They undertake university-wide and individualized activities aimed at equalizing educational opportunities for students and doctoral students experiencing disabilities, while maintaining the same substantive requirements for all students. Some of them, usually the largest and most effective ones, also have a promotional and informative function. They exchange experiences in the form of scientific conferences, cooperation between programs and grants or publications (Giermanowska \& Racław, 2014; Kilian, 2016).

Ewa Giermanowska and Mariola Racław (2014) emphasize that while the total number of students started to decline gradually from the 2006/2007 academic year, the number of students with disabilities is constantly growing. The increase in the number of students with disabilities was possible thanks to the change in the law on higher education, which obligated universities to take measures to adapt education infrastructure and programs to the needs of students with disabilities. It should be noted the Act of 27 July 2005, the Law on Higher Education (pl. Ustawa z dnia 27 lipca 2005 r. Prawo o szkolnictwie wyższym). According to this document, access to studies is to be granted to everyone who meets the substantive requirements, regardless of physical and health limitations. Universities were obliged to "create conditions for disabled people to fully participate in the education process and in research" (Kilian, 2016). In 2012, an amendment to the Act on Higher Education entered into force. An important change resulting from the amendment to the act was the extension of activities supporting also doctoral students with disabilities. It was a group previously forgotten by 
the legislator. Doctoral students, similarly to first and second cycle students, have been able to use a special scholarship for people with disabilities since 2012, the amount of which depends on the degree of disability (Sztobryn-Giercuszkiewicz 2016).

Higher education institutions receive support for these tasks from the State Fund for Rehabilitation of Disabled Persons (pl. Państwowy Fundusz Rehabilitacji Osób Niepełnosprawnych) and EU funds. Currently, at most universities, there are plenipotentiaries for people with disabilities, and often also separate offices for matters. These institutions support students in the education process, provide advisory bodies to university authorities and exchange experiences with other countries. Less comprehensive information has been gathered on doctoral students with disabilities. According to the data of the Central Statistical Office (2018), in 2016, 1,054 people out of a total of 43,181 doctoral students received a special scholarship for people with disabilities. However, it should be emphasized that only people with legally certified disability are eligible for such a scholarship, so it can be concluded that the presented number is underestimated (Wróblewska 2018). The international agreements signed by Poland (e.g. the Universal Declaration of Human Rights, the Convention on Combating Discrimination in the Field of Education, the International Covenant on Economic, Social and Cultural Rights) show that the lack of a ruling cannot limit the right to equal educational opportunities. The starting point for adaptation activities should be the functional limitations resulting from the reduced physical, mental or mental performance of a given person (Waszkielewicz, 2011; Kilian, 2016).

\section{The situation of doctoral students with disabilities at universities}

Many studies have been devoted to the situation of students with disabilities in the academic community, the results of which are presented, among others, in a separate periodical entitled Student Niepełnosprawny. Szkice i rozprawy published by the University of Natural Sciences and Humanities in Siedlce since 1997. The first data on the scale of the phenomenon comes from this year. Over the past two decades, the problem has been recognized and many initiatives have been taken to help this group. These activities increase the percentage of people with disabilities studying, both at public and private universities. The barriers faced by PhD students differ from those of students with disabilities (Farrar, 2006), but research very rarely documents the experiences of $\mathrm{PhD}$ students with disabilities. International studies of doctoral students with disabilities indicate that they constitute $5 \%$ to $10 \%$ of the population of university graduates, and their number is constantly growing (Martin et al., 2011). However, the literature on the subject lacks in-depth information on the situation of doctoral students with disabilities. Michelle Lizotte and Stacy C. Simplican (2017) indicate that most of the 
literature on the situation of doctoral students with disabilities is based on interviews with a small number of respondents or on broader surveys aimed only at academic staff or students with disabilities - while ignoring doctoral students with disabilities.

When applicants are accepted into to doctoral programs, they face environmental obstacles inside and outside the university. They affect their ability to participate in conferences (both national and international), university seminars, meet with the university representative for disabled people or meet their peers. Research shows that doctoral students with visual disabilities encounter inaccessible university websites, difficulties in obtaining materials for classes with students, as well as materials needed to write a doctoral dissertation (Farrar \& Young, 2007; Perez, 2013), as well as in access to public transport (Galdi, 2007). Therefore, an important challenge in the process of adapting the academic education system to the needs of disabled doctoral students is the creation of reading collections in alternative forms. This is related to the digitization of library collections and making them available to PhD students with difficulties in reading the print. Some academic centers (e.g. the University of Warsaw, Wrocław University of Technology, AGH University of Science and Technology in Kraków) implement a system of adapting teaching materials for people with impaired eyesight, thus setting an example for other universities (Kilian, 2016). PhD students with motor disabilities reported difficulties in getting to their office and the supervisor (and classrooms) (Farrar \& Young, 2007).

In 2014, work was underway on the Alternative Social Report (pl. Społeczny Raport Alternatywny z realizacji Konwencji o prawach osób z niepełnosprawnościq w Polsce) on the implementation of the Convention on Persons with Disabilities in Poland. It was created in the process of consultation with people with disabilities, representatives of circles representing their interests and non-governmental organizations. With regard to the area of higher education, the authors of the report particularly emphasized the problem of insufficient support for doctoral students with disabilities, including discriminatory practices in the field of granting grants, where the application process takes place through internet portals that do not comply with WCAG 2.0 standards. The report indicates the limited participation of doctoral students and academic staff with disabilities in the Erasmus program. So far, the experience of young scientists with disabilities, participation in international cooperation outside the Erasmus program is very limited. It is not possible to subsidize the special needs of a young researcher with a disability, such as an assistant to a blind person during field research or a sign language interpreter (Wróblewska, 2018)

In the study "Doktoranci 2015" conducted by the Doctoral Forum of Polish Universities (in cooperation with the Alumno Foundation, the Institute of Economic and Social Research and the Scientific Circle of Doctoral Students of the Faculty of Humanities, UMCS) 3.3\% of the respondents were doctoral students with disabilities (of which 
76.9\% had a certificate about disability). Their basic problem was the maladjustment of infrastructure at universities or faculties: $8.7 \%$ believe that their units are not adapted to the needs of people with disabilities, $43.5 \%$ - that universities are partially adapted, and $37.7 \%$ - that universities are fully adapted. A certain problem may be their perception of the adaptation of infrastructure in terms of the type of disability they suffer, for example, a visually impaired person may pay attention to signs with information in Braille, and not to wheelchair ramps (Bień, 2016). The audit carried out by the Supreme Audit Office (pl. Najwyższa lzba Kontroli) showed that all the audited universities undertook activities to ensure conditions for education for disabled students and doctoral students. However, these actions were not always effective. In seven out of 15 audited universities, the process of educating disabled students and doctoral students in scientific research still did not follow the rules that applied to non-disabled people. We are talking about architectural barriers that hinder or even prevent access to university facilities, as well as difficulties in accessing the full educational offer. During the inspection it was found that the current system of allocating subsidy funds for creating conditions for the full participation of disabled students and doctoral students in the education process did not make the amount of funds awarded to universities dependent on the actual needs. As many as 13 out of 15 universities did not fully use the funds allocated for this purpose, and in the extreme case less than $1 \%$ of the received grant amount was spent. Attention should also be paid to the lack of an obligation for the university to report and account for publicly received earmarked subsidies. This was conducive to the phenomenon of "saving" funds for ongoing support for disabled students and doctoral students (NIK, 2018). It should be emphasized that after the audit by the Supreme Chamber of Control was completed, the Act of July 20, 2018, Law on Higher Education and Science (pl. Ustawa z 20 lipca 2018 roku Prawo o szkolnictwie wyższym i nauce), entered into force. The basic tasks of the university include creating conditions for people with disabilities to fully participate in admission to the university, education and conducting scientific activities. It is important that the measures related to providing people with disabilities with conditions for doctoral studies or conducting research activities contribute to the disability support fund, which should be established at each university (Marcinkowski \& Wanic, 2018).

Doctoral students use various strategies to overcome these obstacles, perhaps the most important of which is a strong relationship with the support office for people with disabilities, which can become an ally in receiving additional help (including accommodation in a dormitory). Other strategies also include looking for places accessible to people with disabilities, where they can rest, meet friends (Jacklin, 2011), as well as participating in smaller scientific conferences where they can navigate more easily, or participating in remote conferences (Grundy \& McGinn, 2008). Doctoral students with disabilities also recommend raising the awareness and level of knowledge 
of the specific functioning of people with various types of disabilities among scientific, didactic, administrative and technical employees and the inclusion of these issues into the academic system of training and promotional activities, as well as teacher education programs. It is important that the activities supporting disabled doctoral students at Polish universities should be systemic and targeted at the entire academic community (Kilian, 2016).

\section{Conclusions}

It should be emphasized that difficulties in functioning at universities by doctoral students with disabilities are specific (mainly related to the specificity of limitations, e.g. deficiencies in the knowledge of the Polish language resulting from the lack of hearing experience of students with hearing impairments) and general (experienced by all students, i.e. stress related to exams and new content to be mastered during the course). Disability cannot limit the perception of a person affected by it or determine its future. The opening of higher education to people with disabilities is a big step on the way to the emancipation of this social group. Despite the shortcomings in education indicated in this study, the imperfection of the current solutions does not abolish their legitimacy, on the contrary, the period of study may become a time of intensive development to self-awareness in building one's future. As part of equalizing educational opportunities for people with disabilities, the aim of higher education in Poland should be to achieve such participation in the academic community that the percentage of disabled university graduates is comparable to the percentage of non-disabled people educated at this level.

Recommendations for the higher education system and environmental institutions in the field of education of doctoral students with disabilities:

1) increasing awareness of disability among university employees, training in special educational needs and teaching adults with disabilities;

2) most research focuses on currently admitted doctoral students, but we do not know how many doctoral students with disabilities resign from doctoral studies (currently doctoral schools), and whether they do so for reasons related to disability, inaccessible infrastructure or a hostile environment (Lizotte \& Simplican, 2017). That is why it is important to employ specialists, in particular people involved in supporting the education of doctoral students with disabilities, assistants of the disabled, psychologists, career counselors, sign language interpreters;

3) increasing the effectiveness of the university Offices for Persons with Disabilities by disseminating information about the support provided. There is a lack of more 
structured research on the relationship between a disabled doctoral student and the office. The following questions should be asked: What proportion of doctoral students with disabilities discloses their disability to offices of disability services? What are common issues that offices of disability services address for doctoral students? How do these issues differ from the kinds that undergraduate students face? (Lizotte \& Simplican, 2017).

4) gradual removal of architectural, infrastructural and digital barriers, equipping universities with specialized equipment supporting the education of people with disabilities.

\section{Bibliography}

Bień, D. (2016). Studia trzeciego stopnia w polskich uczelniach - funkcjonowanie, diagnoza, rekomendacje. Nauka i szkolnictwo wyższe, 1(47), 247-277.

Brzeziecki Ł., \& Pietrzak P. (2018). Efektywność i skuteczność studiów doktoranckich w publicznym szkolnictwie wyższym w Polsce. Gospodarka Narodowa, 2(294), 129-159.

Całek, A., et. al. (2011). Losy zawodowe osób ze stopniem naukowym doktora w kontekście polityki Unii Europejskiej w zakresie szkolnictwa wyższego. Zarządzanie Publiczne, 1(13), 153-187.

Czerepaniak-Walczak, M. (2013). Studia doktoranckie w systemie szkolnictwa wyższego i w społeczeństwie wiedzy: komu i do czego potrzebne są studia doktoranckie na kierunku/w dyscyplinie Pedagogika. Rocznik Pedagogiczny, 36, 69-82.

Czerw, M., Karpuszenko E., \& Kukla D. (2019). Niepełnosprawni w szkolnictwie wyższym - stan obecny i perspektywy. Szkoła-Zawód-Praca, 18, 150-159.

Farrar, V. (2006). Equal to the task: Disability issues in postgraduate research study. In: M. Adams, \& S. Brown (Eds.), Towards inclusive learning in higher education: Developing curricula for disabled students (pp. 176-187). Routledge.

Farrar, V., \& Young, R. (2007). Supervising disabled research students: Issues in postgraduate education: Management, teaching and supervision. Society for research into higher education, 2(3).

Fundacja, K.S.K. (Eds.). (2015). Społeczny Raport Alternatywny z realizacji Konwencjio prawach osób z niepełnosprawnościami w Polsce. Warszawa.

Galdi, L.L. (2007). Factors that enable graduate students with visual disabilities to succeed in their educational pursuits. Dissertation submitted to Fordham University. EDT.

Giermanowska, E., \& Racław, M. (2014). Pomiędzy polityką życia, emancypacją i jej pozorowaniem. Pytania o nowy model polityki społecznej wobec zatrudnienia osób niepełnosprawnych. Studia Socjologiczne, 2(213), 107-127.

Gromkowska-Melosik, A. (2020). Doktorant jako stopień naukowy. Geneza, znaczenia, kontrowersje. Studia Edukacyjne, 59, 91-102. 
Grundy, A.L., \& McGinn, M.K. (2008). Enabling participation in graduate education: Support for a student researcher who is hard of hearing. International Journal of Disability, Community \& Rehabilitation, 7. http://www.ijdcr.ca.

GUS (2018). Dane dotyczące wykształcenia osób niepełnosprawnych na podstawie Badania Aktywności Ekonomicznej Ludności (do Il kwartału 2018).

Jacklin, A. (2011). To be or not to be a "disabled student" in higher education: The case of a postgraduate "non-declaring" (disabled) student. Journal of Research in Special Educational Needs, 11, 99-106.

Kierznowska, Ł. (2018). Szkoły doktorskie. Komentarz do art. 198-216 ustawy prawo o szkolnictwie wyższym i nauce. Wydawnictwo „Difin”.

Kilian, M. (2017). Student z niepełnosprawnościami: doświadczenia, potrzeby, wyzwania. Forum Pedagogiczne, 1, 267-282.

Krzymowska, E. (2014). Student z niepełnosprawnością w Polsce. Niepełnosprawność, 15, 100-110.

Lizotte, M., \& Simplican, S.C. (2017). Doctoral students with disabilities: challenges in graduate programs and research methodology. Journal for the Study of Postsecondary and Tertiary Education, 2, 181-193.

Marcinkowski, T., \& Wanic, P. (2018). Tworzenie warunków do nauki niepełnosprawnym studentom. Kontrola Państwowa, 63, 142-149.

Melosik Z. (2013). Edukacja uniwersytecka i procesy stratyfikacji społecznej. Kultura - Społeczeństwo - Edukacja, 1(3), 21-46.

Mikołajczyk B., Naskręcki R. (2017). Szkoły doktorskie i ich rola w kształceniu doktorantów. Nauka i Szkolnictwo Wyższe, 2(50), 107-126.

NIK (2018). Realizacja przez uczelnie akademickie i zawodowe obowiązku stworzenia niepełnosprawnym studentom i doktorantom warunków do pełnego udziału w procesie kształcenia i w badaniach naukowych. https://www.nik.gov.pl/kontrole/ $\mathrm{P} / 18 / 087 /$

Perez, L. (2013). The perspectives of graduate students with visual disabilities: A heuristic case study. Doctoral dissertation. University of South Florida.

Powell, J.W., \& Solga, H. (2011). Why are higher education participation rates in Germany so low? Institutional barriers to higher education expansion. Journal of Educational and Work, 24, 49-68.

Społeczny Raport Alternatywny z realizacji Konwencji o prawach osób z niepełnosprawnością w Polsce (2015). http://monitoringobywatelski.firr.org.pl/wp-content/uploads/2015/09/Spo\%C5\%82eczny-Raport-Alternatywny_ostateczny.pdf

Stankiewicz, Ł. (2015). Pułapka umasowienia - o sprawczości jednostek w umasowionym systemie szkolnictwa wyższego. Nauka i szkolnictwo wyższe, 1(45), 191-213.

Swart, E., \& Greyling, E. (2011). Participation in higher education: Experiences of students with disabilities. Acta Academia, 43(3), 81-110.

Sztobryn-Giercuszkiewicz, J. (2016). Alter idem - student z niepełnosprawnością w systemie szkolnictwa wyższego. In: E. Zakrzewska-Manterys, \& J. Niedbalski (Eds.), Samodzielni, 
zaradni, niezależni. Ludzie niepełnosprawni w systemie polityki, pracy i edukacji (pp. 99-145). Łódz: Wydawnictwo Uniwersytetu Łódzkiego.

Szulc, T. (2007). Polskie szkolnictwo wyższe. In. T. Szulc (Ed.), Jakość kształcenia w szkołach wyższych. Wrocław: Oficyna Wydawnicza Politechniki Wrocławskiej.

Śleboda, R. (2012). Kierunek i poziom wykształcenia oraz aktywność zawodowa osób z niepełnosprawnością. Niepełnosprawność - zagadnienia, problemy, rozwiązania, 2, 107-130.

Ustawa z dnia 27 lipca 2005 r. Prawo o szkolnictwie wyższym (Dz. U. 2005 nr 164 poz. 1365)

Ustawa z 20 lipca 2018 r. Prawo o szkolnictwie wyższym i nauce (Dz. U. 2008 poz. 1668)

Waszkielewicz, A. (2011). Prośba do MNiSW o wyjaśnienie statusu osób niepełnosprawnych (nr pisma: FIRR/2011-09-19/AW/PIS/1). Fundacja Instytut Rozwoju Regionalnego.

Wróblewska, A. (2018). Dostępność polskich uczelni: wdrażanie art. 24 Konwencji o Prawach Osób Niepełnosprawnych (KPON) w obszarze szkolnictwa wyższego. Studia z Polityki Publicznej/Szkoła Główna Handlowa, 4, 45-65. 